\title{
Weighting Approaches on Online Sexual Abuse of Children: Cultural Prevention or Crime-Based Enforcement?
}

\author{
Ahmad Sofian* \\ Business Law Program, Law Department, Faculty of Humanities, \\ Bina Nusantara University, Jakarta. \\ Bambang Pratama** \\ Business Law Program, Law Department, Faculty of Humanities, \\ Bina Nusantara University, Jakarta.

\section{Chiara Talerico***} \\ Crime Analysis, Elephant Action League, Los Angeles.
}

\begin{abstract}
Online Child Sexual Exploitation (OCSE) is a form of crime against children that can be reviewed from various perspectives such as criminal law, criminology and culture. This offence is governed in several international legal instruments because perpetrators and victims are often located in different territories or have different nationalities. The Optional Protocol on Sale of Children, Child Prostitution and Child Pornography (OPSC) is one that provides a reference in combating this crime, but this instrument has the disadvantage of not providing specific guidance in overcoming sexual crimes of children who are in the online sphere. OPSC focuses more on child pornography, whereas OCSE has evolved rapidly enough to give birth to new forms of crime that are not just child pornography. Another weakness can be found in national laws, due to the lack, or limited, response to address the issue. Therefore, a cultural approach is important to prevent and tackle this problem. This paper is aimed to weight the needs to use a Preventive Cultural approach and a CrimeBased Enforcement in addressing Online Sexual Abuse in Indonesia. It is a normative legal research that reads various primary and secondary legal materials. The study recommends that there is a need to use appropriate legal terminology and provide a clear interpretation of the terminology in national law so that these crimes can be quickly addressed. In addition, it also argued that cultural approaches may be used to prevent the occurrence of OSCE by means of involving the community and religious leaders, educating family, as well as raising the awareness of children.
\end{abstract}

Keywords: Sexual Abuse of Children; Internet; Crime; Cultural Approach; Indonesia.'

How to cite (chicago-16th): Sofian, Ahmad, Bambang Pratama, and Chiara Talerico. "Weighting Approaches on Online Sexual Abuse of Children: Cultural Prevention or Crime-Based Enforcement?"Udayana Journal of Law and Culture 2, no. 2 (2018): 191-219. https://doi.org/ 110.24843/UJLC.2018. v02.i02.p04.

DOI: https://doi.org/ 10.24843/UJLC.2018.v02.i02.p04

\footnotetext{
Email /Corresponding Author: asofian@binus.edu and ahsofian@gmail.com

** Email: bpratama@binus.edu

*** Email chiaratale@yahoo.it
} 


\section{Introduction}

\subsection{Background}

Indonesian people represents the same situation of Southeast Asian countries' people, indicates the lack of awareness of the risks of online child grooming and child sexual abuse. ${ }^{1}$ Indonesian children were targeted for pornography crime and exposure to pornography. There are a number of facts that children in Indonesia have subjected to pornography both by unorganized criminals and by organized criminals to be commercialized. One of the most shocking facts is the case that was revealed in May 2017, in which a father, lives in Kutai Kartanegara regency, East Kalimantan, had a regular sexual scene with his daughter that is connected with Skype to be broadcast live and witnessed by paedophiles around the world. ${ }^{2}$

In January 2018, Indonesian Ministry for Communication and Information received some 8.166 complains regarding the pornography contents. ${ }^{3}$ After 2017, the ministry blocked almost 800,000 sites, in which more than 90 per cent of these sites were pornographic. ${ }^{4}$

A Commissioner of the Indonesian Child Protection revealed that the commission had seen the results of the screening conducted by Indonesian Ministry of Health that to primary school children by the end of 2017 and published in March 2018. It is a shocking fact that the data shows that $91,58 \%$ of the 6.000 samples taken have been exposed to pornography, some $6,3 \%$ have experienced light pornography addiction, and some $0.07 \%$ experienced heavy addiction. ${ }^{5}$ Another survey also discovered a shocking data as $97 \%$ of respondents, junior and senior high school students in 12 big cities in Indonesia have admitted themselves ever accessing sites that offer pornography content and watching porn video through the internet. ${ }^{6}$

Currently, Internet use remains largely concentrated in Indonesia's major cities, where people are better able to afford internet-enabled devices, but as technological developments continue and prices drop, this is expected to spread into more rural

\footnotetext{
1 Deanna Davy "Regional Overview: Sexual Exploitation of Children in Southeast Asia” Bangkok: ECPAT International, September 2017, 54.

2 Nabila Maharani “Bejat! Ayah Tega Cabuli Anaknya Secara Live Di Grup Pedofil” May 11, 2017, https:/ /www.inspiradata.com/bejat-ayah-tega-cabuli-anaknya-secara-live-grup-pedofil/

3 Tempo, “Kominfo Kantongi 8.166 Aduan Konten Pornografi di Januari 2018”, Bisnis.Com-Tempo. Co, February 23, 2018.https://bisnis.tempo.co/read/1063823/kominfo-kantongi-8-166-aduan-kontenpornografi-di-januari-2018

4 Reuters, New Indonesia Internet System Blocks More Than 70,000 'Negative' Sites, Jakarta, February 19, 2018, http://indianexpress.com/article/technology/tech-news-technology/new-indonesiainternet-system-blocks-more-than-70000-negative-sites-5069746/

5 Davit Setyawan, "KPAI: Darurat Pornografi pada Anak SD, Orangtua Harus Tingkatkan Pengawasan", March 31, 2018, http://www.kpai.go.id/berita/kpai-darurat-pornografi-pada-anak-sdorangtua-harus-tingkatkan-pengawasan

6 Ahmad Budiman, "Pemblokiran Konten Porno pada Layanan over the Top," Info Singkat Pemerintahan Dalam Negeri IX, no. 22 (November 2017): 18.
} 
areas. ${ }^{7}$ A popular way to go online is through mobile internet. The use of Smartphones and tablets are on the increase, but internet-capable feature phones are still the preference of the majority of mobile Internet users. ${ }^{8}$ Indonesians use the Internet predominantly for information and communication purposes, especially via internetbased instant messages, such as Blackberry Messenger, and social media, such as Facebook.

Indonesia has been listed as one of the top 10 countries with the highest cases of online sexual abuse of children since 2005. 9 The recently arisen issue of OSAC has received great attention from various parties, including government institutions, non-governmental organizations and media. Cases of OSAC that have been reported in the media have fuelled national concern about the safety of children online and raised questions of the magnitude of OSAC and how it can be prevented.

It is worth to make known that mainstream views in Indonesia tends to urge the use of criminal law means to enforce the perpetrator. They thought that criminalizing the doer will bring an impact, especially psychological deterrence, to the potential perpetrator. It is also interesting to discover that some non-legal approaches have been used to provide a breakthrough of this matter. For example, research conducted by Prima Angkupi offers moral and cultural approaches to prevent cyberporn crime. ${ }^{10}$ The author argues that as cyberporn in nature is contradicts both norm and culture, it can be resolved by strengthening the moral and legal culture of the society. ${ }^{11}$ These two perspectives, cultural approach and criminal law, will become the main issue of this article.

\subsection{Purposes}

This article investigates the specific role of Internet access in child sexual abuse, determine different forms of online abuse, and attempts to characterize the magnitude of this issue in Indonesia. Additionally, this research aims to make a first step in indicating possible factors that contribute to the online sexual abuse of children and formulates recommendations on how to combat this phenomenon. It is also aimed at determining some contributing factors to online child abuse and

7 Emarketeer, In Indonesia a New Digital Class Emerges: Internet and Mobile Internet Will See Significant Adoption in the Next Few Years. Retrieved from http:/ / www.emarketer.com/Article/ Indonesia-New-Digital-Class-Emerges / 1009723

8 Ibid.

9 Kompas, “Situs Porno Kian Mengkhawatirkan,” Kompas.com, March 16, 2012, https:// travel.kompas.com/read/2012/03/16/02354152/Situs.Porno.Kian.Mengkhawatirkan\%E2\%80\%A $\mathrm{C} \% \mathrm{E} 2 \% 80 \% \mathrm{AC}$ and Margie Mason, "Facebook Used to kidnap, traffic Indonesian girls," USA Today, October 30, 2013. http://www.usatoday.com/story/news/world/2012/10/29/facebook-used-tokidnap-traffic-indonesian-girls / 1665321/

10 Prima Angkupi, "Cultural Approaches in Cyberporn Crime Prevention", Jurnal Dinamika Hukum 17, no.2 (May 2017): 225, 231.

11 Ibid, 230. 
formulate recommendations on how to combat online child abuse. Those issues are formulated in a general purpose of this writing that is to weight the needs to use a Preventive Cultural approach and a Crime-Based Enforcement in addressing Online Sexual Abuse in Indonesia.

\subsection{Method}

As a legal research, this writing reads some relevant legal instruments, both international legal instruments and national law and regulations of Indonesia. Concepts and reviews are cited from textbooks and academic papers while facts are very much obtained from government and non-governmental organizations reports, online sources, and interview. By virtue of providing comparative insights, this writing also looks at case studies and developments of regulating as well as enforcement measure imposed to online Sexual Abuse of Children, as can be traced from relevant reports and publications.

\subsection{Literature Review}

Several research studies have found the effects of watching online pornographic materials on children to be detrimental. Watching pornography can cause a child to experience distress and can cause a child to adopt unhealthy notions of sex and relationships. ${ }^{12}$

A recent study regarding online child sexual exploitation offending was carried out by Tony Krone and Russell G Smith by taking a study focus in Australia. ${ }^{13}$ It aims at improving the understanding of the risks posed by those investigated by the Australian Federal Police (AFP) for online-only CSE offences, principally online CEM offences with some grooming offences. ${ }^{14}$ The result of the study shown that of the 152 offenders, 148 (97\%) were CEM offenders convicted of at least one CEM index offence, 131 (86\%) were offenders convicted of CEM-only offenders, and 17 (11 percent) were convicted of index offending involving both CEM offending and either grooming or contact offences (dual CEM offenders). ${ }^{15}$ The study also revealed that a median collection size of offenders is 1.000 files (a file being a single item like an image or a video); 25 per cent had collections of more than 10,000 files and five per cent had collections of over 100,000 files. ${ }^{16}$

12 Michael Flood, "The Harms of Pornography Exposure Among Children and Young People." Child Abuse Review, 18 (2009): 384-400.

13 Tony Krone and Russell G Smith, "Trajectories in Online Child Sexual Exploitation Offending in Australia," Trends \& Issues in Crime and Criminal Justice 524 (2017).

14 Ibid.

15 Ibid, 6.

16 Ibid, 7. 
Mohamed Chawki is an Egypt law practitioner as well as a scholar that pays attention to the issue of online sexual abuse of Children. He made a critical assessment of the problem of Internet child sexual abuse and its governance through both French legal and non-legal means. ${ }^{17}$ In discussing French approach to child abuse regulation, he realizes that there appears not to be a single solution for the regulation of illegal and harmful content on the internet because countries defined child pornography offences in various ways and the meaning of 'harmful' will depend upon cultural differences. ${ }^{18}$ This study also recommends law-makers to develop forfeiture laws, similar to those used for drug traffickers, to seize the property of child pornographers and abusers to pass legislation prohibiting the mere possession of child pornography and to translate their criminal codes to facilitate international cooperation. ${ }^{19}$ Chawki, in a joint article with Yassin el Shazly, addresses the growing threat of sexual harassment in cyberspace and provides an overview of the issues and risks pertinent to sexual harassment and seeks to offer some solutions based on the necessity of pursuing a tri-fold policy encompassing strategic and regulatory, technical, and cultural approaches. ${ }^{20}$

Some Indonesian scholars have carried out a study that highlights the issue of pornography through the internet. HwianChristianto identified functions of act against material law for pornography criminal act through the internet and inquiries whether or not judges in Indonesia applied act against the material law in considering the verdict of pornography case through the internet. ${ }^{21}$ The study discovers that Judge, in practice, applied morality norm as a source of defamation of pornographic acts through the internet in case legal provisions was relatively unclear. ${ }^{22}$ Angga Astian Putra et.al conducted a research that asses whether or not law and regulations in Indonesia have provided protection in preventing them becoming a victim of an internet-based crime of pornography as well as discusses the ideal policy to be issued in resolve the case in concern. ${ }^{23}$ While the result shows that Indonesian law and regulations have included some legal protections, although not comprehensively yet, authors recommend the establishment of a special agency that is authorized to oversee and assess sites or online games that are allowed to a certain age of children. ${ }^{24}$

17 Mohamed Chawki, Child Sexual Abuse: The French Response, Journal of Digital Forensics, Security and Law 4, no.4 (2009): 9.

18 Ibid, 25.

19 Ibid, 35.

20 Mohamed Chawki and Yassin el Shazly, "Online Sexual Harassment: Issues and Solutions," Journal of Intellectual Property, Information Technology and Electronic Commerce Law 4, no.2 (2013): 71.

21 Hwian Christianto, "Imposition of Nature Against Material Law under Judge Verdict of Cyberporn Case In East Java," Jurnal Dinamika Hukum 17, no. 3 (2017): 289.

22 Ibid, 294.

23 Angga Astian Putra, Prija Djatmika, and Nurini Aprilianda, Bentuk Perlindungan Hukum bagi Anak agar Tidak Menjadi Korban dari Tindak Pidana Pornografi melalui Situs Internet," Jurnal Hukum (2016): 3-4.

24 Ibid, 20. 
Some research on the legal protection of children has not highlighted the issue of online sexual abuse of children. Wilson Ola Diriwari conducted an academic PhD research that focuses on the issue of child trafficking in Nigerian society in order to demonstrate the ineffectiveness of law and policies approaches, both at international and national levels, to address the issue in concern. ${ }^{25}$ The research was very much looking at some concepts and theories such as child abuses, child exploitation, and child protection, cultural relativism, social constructionism, and legal pluralism. ${ }^{26}$ This thesis finally urges that traditional approaches to child abuses, child protection, and the pressure of economic realities in Nigeria require an immediate response and also postulates that the way forward for Nigeria can be found in new legal, political, as well as socio-economic paradigms. ${ }^{27}$

\section{Result and Analysis}

\subsection{Online Sexual Abuse of Children: Terms and Concepts}

Children can be inducted into exploitation by making use of a position of supremacy, a vulnerability or other circumstances. In other cases, the child could believe the sexual exploitation being an integrated part of a loving relationship with a trusted adult.

Literature has discovered any form of children and formulated some definitions. Sexual abuse in one among four kinds of abuses to which a child is usually subjected. The others types are physical, neglect, and emotional. ${ }^{28}$ It may be defined as the sexual molestation of children by adults or older children that leads to sexual arousal in the perpetrator. ${ }^{29}$

Online sexual abuse of children (hereinafter, OSAC) is a form of child sexual abuse, which takes place on, or is facilitated by the Internet. In cases of OSAC, the internet has used either primary, for example by using the internet to display and distributing child abuse material, or secondary, by using the internet to get in contact with children to facilitate offline child sexual abuse, prostitution and trafficking. In this research, Online child sexual abuse (OSAC) is meant in the broadest sense of the word: Any form of child sexual abuse, on or facilitated by the Internet.

There are some other phrases to indicate the issue of OSAC. One example is Online Child Sexual Exploitation (OCSE), as used by ECPAT International and

25 Wilson Ola Diriwari, "Efficacy of the Legal Frameworks for Child Protection in Nigeria" (PhD diss., Department of Politics, History and the Brunel Law School Brunel University London, 2016$), 37$.

26 Ibid, 233.

27 Ibid, 234.

28 Wilson Ola Diriwari, Op. Cit, 31.

29 Ibid, 37-38. 
Religions for Peace (RfP). ${ }^{30}$ They also prefer to use term "Child sexual abuse material (CSAM)"31 instead of "child pornography", and term "child sexual exploitation material" (CSEM) to encompass all other sexualised material depicting children in a broader sense. ${ }^{32}$ Despite CSEM, some other studies are in favour of using child exploitation material (CEM) to indicate sexually abusive images of children and to refers to child pornography. ${ }^{33}$

Child abuse material, also often called child pornography, and the Internet seems to be entangled, and information technology plays a crucial role in possession, circulation and production of child abuse images. ${ }^{34}$ Child abuse material exploits children in many ways: ${ }^{35}$

- Children may be tricked or coerced into engaging in sexual acts for the production of child abuse material. These images are then sold, traded or otherwise distributed.

- The demand for images of children maintains the incentive to produce such materials. Thus, those who "consume" and/or possess abusive depictions of children continue to exploit these children.

- Child abuse materials are frequently used by child abusers to dimish a child's inhibitions and to convey the impression that sex between adults and children is normal, acceptable and enjoyable. This is part of the "grooming" process.

- The makers of child abuse material commonly use their "products" to coerce, intimidate or blackmail the children used in the making of such material.

\subsection{International Concern on Online Sexual Abuse of Children}

During the period 2016-2017, the United Nations published the UN Glossary on Glossary on Sexual Exploitation and Abuse. ${ }^{36}$ It defines sexual abuse as "Actual

30 ECPAT International and Religions for Peace, "Protecting Children from Online Sexual Exploitation: A Guide to Action for Religious Leaders and Communities,", June 2016, 4. https://www.unicef.org/protection/files/FBO_Guide_for_Religious_Leaders_and_Communities_ENG(1).pdf

31 See also Mohamed Chawki, Op.Cit, 11.

32 Ibid, 7.

33 Tony Krone and Russell G Smith, Op.Cit, 1-2. See also Carmen Madrinan, "Worst Form of Child Labor: Commercial Sexual Exploitation of Children", in The World of Child Labor: An Historical and Regional Survey, ed. Hugh D Hindman (New York: Routledge, 2015), 97.

34 John Carr. Child Abuse, Child Pornography and the Internet (London: NCH, 2004).

35 Catherine Beaulieu, Strengthening Laws Addressing Child Sexual Exploitation (Bangkok: ECPAT International, 2008).

36 United Nations Glossary on Sexual Exploitation and Abuse Thematic Glossary of current terminology related to Sexual Exploitation and Abuse (SEA) in the context of the United Nations Second Edition, Prepared by the Task Team on the SEA Glossary for the Special Coordinator on Improving the United Nations Response to Sexual Exploitation and Abuse. The first version was created on 5 October 
or threatened physical intrusion of a sexual nature, whether by force or under unequal or coercive conditions. ${ }^{37}$ In addition, the Glossary made the following comments: "All sexual activity with a child is considered as sexual abuse. 'Physical intrusion' is understood to mean 'sexual activity'. 'Sexual abuse' is a broad term, which includes a number of acts described below, including 'rape', 'sexual assault', 'sex with a minor', and 'sexual activity with a minor'. The Glossary explicitly refers to the problem of consent when defining that both 'sexual penetration of' and 'sexual activity with' a child is prohibited regardless of the age of majority or consent locally and is considered as sexual abuse."38

Another UN product, the Sustainable Development Goals targeted the elimination of all forms of violence against all women and girls in the public and private spheres, including trafficking and sexual and other types of exploitation as well as an End of abuse, exploitation, trafficking, and all forms of violence against and torture of children. ${ }^{39}$ SDG 8.7, in accordance with International Labour Organization (ILO) Convention 182, is also not in favour of the use, procuring or offering of a child for prostitution, for the production of pornography or for pornographic performances. As a broader shield, the agenda features children protection, in order to ensure every child grows up free from exploitation of every kind.

Deputy High Commissioner for Human Rights Kate Gilmore said that online sexual exploitation is likely to rise in the coming years with the demand for new child sexual abuse material. She also reveals fact that many States do not have an adequate legislative framework to perform thorough investigations into and prosecution of online sexual exploitation and abuse of children. ${ }^{40}$

The Global Alliance Against Child Sexual Abuse Online, launched by the European Commission and the US in 2012, was established to raise standards worldwide and unite efforts around the world to more effectively combat online sexual crimes against children. ${ }^{41}$ Its Report in December 2013 comprises four policy targets that further detailed in specific operational goals and actions. ${ }^{42}$ One of the targets is Reducing as much as possible the availability of child pornography online and

2016 and was modified into the Second Edition on 24 July 2017.https://hr.un.org/sites/hr.un.org/ files / SEA\%20Glossary\%20\%20\%5BSecond\%20Edition\%20-\%202017\%5D\%20-\%20English_0.pdf

37 Ibid, para 4.

38 Ibid, para 10-11.

39 United Nations General Assembly (2015), "Transforming our world: the 2030 Agenda for Sustainable Development", UNDOC, A/70/L.1, 5.2 and 16.2.

40 The Office of the United Nations High Commissioner for Human Rights, "New Digital Technologies Produce Unprecedented Levels of Child Abuse Material Online", 18 March 2016.

41 European Commission, Migration and Home Affairs, "The Global Alliance Against Child Sexual Abuse Online". https://ec.europa.eu/home-affairs/what-we-do/policies/organized-crimeand-human-trafficking/global-alliance-against-child-abuse_en

42 European Commission, Home Affairs, Report of the Global Alliance against Child Sexual Abuse Online, December 2013, 7-21. 
reducing as much as possible the re-victimization of children whose sexual abuse is depicted that is implemented by action of improving cooperation between law enforcement and the private sector in the fight against child sexual abuse online in an appropriate legal framework and development and use of technologies and training to identify and remove child pornography images. ${ }^{43}$

Two leading international non-governmental organizations, ECPAT International and Religions for Peace, jointly initiated an establishment of A Guide to Action For Religious Leaders and Communities that is aimed to Protect Children from Online Sexual Exploitation. This guide was expected to provide some basic tools to equip religious leaders and communities to act, advocate, educate, and collaborate both among themselves and with broader initiatives so that each and every child can live without fear, develop their true potential and enjoy the inviolable gift of their human dignity. ${ }^{44}$

In the international context, there are several regulations that are used as the basis for criminalizing child sex offenders online. ${ }^{45}$ For example, the Optional Protocol on Sale of Children, Child Prostitution and Child Pornography (OPSC) to the Convention on the Rights of Child. Article 3 OPSC expresses the act of offering, transmitting or receiving in any way, a child for the purpose of sexual exploitation of the child. In addition, the act of creating, distributing, distributing, importing, exporting, selling or possessing child pornography for the purpose of sexual exploitation of children is prohibited and criminalized. International Labour Organization (ILO) also contributed on the war against child labour that may lead to a child sexual exploitation by creating The ILO Convention on the Author and Immediate Action for the Abolition of the Worst Forms of Child Labor. This Convention does not contain any definition of 'child pornography' or CSAM/CSEM but it does make clear that "the use of, the attempt to obtain or offer a child for prostitution, the manufacture of pornography or pornographic performances" can be defined as one of the worst forms of child labour. ${ }^{46}$

\subsubsection{Development in Europe}

In Europe, Council of Europe Convention on the Protection of Children against Sexual Exploitation and Sexual Abuse was established to prevent and combat sexual exploitation and child sexual abuse, to prevent and protect the rights of victims and to promote national and international cooperation. This convention reflects a

43 Ibid, 18-19.

44 ECPAT International and Religions for Peace, Op. Cit, 2.

45 African Charter on the Rights and Welfare of the Child (ACRWC), Article 2; ECPAT International and ECPAT Luxembourg, Op. Cit., p. 5-6.

46 ILO Convention No. 182 concerning the Prohibition and Immediate Action for the Elimination of the Worst Forms of Child Labour. 
progressive nature as it became the first international instrument that enables the criminalization for acts of solicitation of children for sexual purposes through ICT, as stipulated in Article 23. When assessing the context of solicitation, The Committee of the Parties of this Convention recommends State Parties to consider encouraging law enforcement to prevent the commission of sexual offences against children, including online grooming, through ICT. ${ }^{47}$ The Committee also made a note on the progress in Spain, where its national authority and autonomous communities manage a national online database containing the transferred data (Registro Unificado de Maltrato Infantil/Unified Child Abuse Register) ${ }^{48}$ In addition, The Council of Europe Convention on Cyber Crimes also sets an obligation for State Parties to adopt such legal measures to establish criminal offences for any act of making child pornography through a computer system; offer or provide child pornography through a computer system and distribute or transmit child pornography through a computer system. ${ }^{49}$

Article 4 of the European Union Directive on Combating the Sexual Abuse and Sexual Exploitation of Children and Child Pornography (Directive 2011/93/ EU) ${ }^{50}$ defines sexual exploitation as "Causing or recruiting a child to participate in pornographic performances, or profiting from or otherwise exploiting a child for such purposes" as well as "Coercing or forcing a child to participate in pornographic performances, or threatening a child for such purposes". In the first case, the offence is punishable by a maximum term of imprisonment of at least 5 years when the age of consent was not reached or 2 years when the age requirement is met. In the second case, the maximum term of imprisonment in the absence of the age of consent is 8 years, otherwise is 5 years. The Directive punishes as well the mere attending pornographic performances with a maximum imprisonment term of 2 or 1 year according to the age of consent requirement. The maximum penalty of 10 years is reserved to "coercing or forcing a child into prostitution or threatening a child for such purposes".

European Financial Coalition (EFC) identifies commercial sexual exploitation of children as the sale of child abuse images. "This could include a website designed

47 Committee of the Parties to the Council of Europe Convention on the Protection of Children Against Sexual Exploitation and Sexual Abuse (T-ES), "Opinion on Article 23 of the Lanzarote Convention and its Explanatory Note Solicitation of Children for Sexual Purposes through Information and Communication Technologies (Grooming)," Adopted by the Lanzarote Committee on 17 June 2015, para 16.

48 Committee of the Parties to the Council of Europe Convention on the Protection of Children Against Sexual Exploitation and Sexual Abuse (T-ES), 1st Implementation Report "Protection of Children Against Sexual Abuse in the Circle of Trust the Framework" Adopted by the Lanzarote Committee on 4 December 2015, para 58.

49 European Treaty Series 185 - Convention on Cybercrime, 23.XI.2001, Art. 9 (1).

50 Directive 2011/93/EU of the European Parliament and of the Council of 13 December 2011 on combating the sexual abuse and sexual exploitation of children and child pornography, and replacing Council Framework Decision 2004/68/JHA, http://eur-lex.europa.eu/legal-content/ EN/ TXT/?uri $=$ celex\%3A32011L0093 
to provide child abuse images for a cost..."51 as well as setting up paid online facilities which can be used to store and/or share abusive contents. It is interesting to note that in some instances the monetary element can as well be absent, still realizing the same offence. This happens, for instance, when the pornographic material is exchanged in order to obtain other abusive material, which becomes the currency itself.

\subsubsection{The Issue of Digitally Generated Images}

The Optional Protocol to the Convention on the Rights of the Child on the Sale of Children, Child Prostitution and Child Pornography (OPSC) includes Art 3(c): ${ }^{52}$ "producing, distributing, disseminating, importing, exporting, selling or possessing 'child pornography' for the purpose of sexual exploitation of the child". However, the Protocol is lacking in the way it excludes from its provision the "accessing and mere possession of child pornography". Although "Child pornography means any representation, by whatever means, of a child engaged in real or simulated explicit sexual activities or any representation of the sexual parts of a child for primarily sexual purposes",53 definition of 'child pornography' is not inclusive of digitally/ computer generated CSAM as defined in the Terminology Guidelines.

The Council of Europe Convention on Cybercrime (Budapest Convention) includes producing, offering or making available, distributing or transmitting, procuring and possessing 'child pornography' through a computer system. Definition of 'child pornography' covers 'realistic images representing a minor engaged in sexually explicit conduct' and 'a person appearing to be a minor engaged in sexually explicit conduct', ${ }^{54}$ but does not make any specific reference to digitally created images.

The Council of Europe Convention on the Protection of Children against Sexual Exploitation and Sexual Abuse (Lanzarote Convention) leaves aside digitally/computer generated CSAM too. Thus, contributing to the existing gap. Art 20 (3), explicitly states that "Each Party may reserve the right not to apply, in whole or in part, paragraph 1.a and $e$ to the production and possession of pornographic material: consisting exclusively of simulated representations or realistic images of a non-existent child"55. The lack of solid international regulations in this sense constitutes an

51 European Cybercrime Centre (EC3) - Europol, "EFC Commercial Sexual Exploitation of Children Online, A Strategic Assessment”, 2015, p. 7, www.europol.europa.eu/publications-documents/ commercialsexual-exploitation-of-children-online

52 P Optional Protocol to the Convention on the Rights of the Child on the sale of children, child prostitution and child pornography. New York, 25 May 2000. https://treaties.un.org/doc/ Treaties/2000/05/20000525\%2003-16\%20AM/Ch_IV_11_cp.pdf

53 Ibid, Art 2 (c).

54 Art 9 (2), Convention on Cyber Crime, 23 November 2001. http://www.europarl.europa.eu/ meetdocs/2014_2019/documents/libe/dv/7_con budapest_/7_conv_budapest_en.pdf

55 Art 20 (3), Council of Europe Convention on the Protection of Children against Sexual Exploitation and Sexual Abuse, CETS No.201, Lanzarote, 25/10/2007 
important issue, because the digitally generated material, although not carrying a physical offence to any child, sustain, anyway, a market for child exploitation and forage a cultural acceptance of sexualization of children.

\subsubsection{The Issue of Transnationality}

When child sexual abuse online is limited to the consumption of child exploitation materials online, without leading to a physical encounter between the victim and the offender, its prosecution faces the issues concerned to transnationality. Due to the nature of the crime, it is often necessary to proscribe transnational criminal activity in order to use online child sexual exploitation legislation.

The most used way to deal with this issue is to "by enabling prosecutions to take place where the accused or victim are located in different jurisdictions as long as there remains a sufficient connection with the place in which the prosecution is commenced." ${ }^{56}$ For example, if someone commits an online crime towards a German citizen, Germany may request extradition from the country the person finds him self in.

An important principle to consider is the criterion of dual criminality. This means that the act must be recognized as an offence under both the laws of the extradition country and the requesting one. The concept can be applied with different strength according to a State to another, Indeed, some require duality for all request for assistance and some other just for extradition purposes. Although this is an internationally binding and recognize principle it is able to create obstacles in the prosecution of online crimes, i.e. online sexual crimes.

In this respect, it is interesting to note that the UK is one of the very few states whose jurisdiction abolished the necessity to respect dual criminality as to child sexual offences. Section 72(1) of the Criminal Justice and Immigration Act $2008^{57}$ (UK) provides that: "if a British citizen commits an act in a country outside the UK, and the act would constitute an offence when committed in England, Wales or Northern Ireland, then the UK national is deemed guilty in that part of UK for that sexual offence".

\subsection{Cultural Approach to Prevent Online Sexual Abuse of Children in Indonesia}

Indonesian children are abused in the making of child pornography. Exact figures are not available, which makes it hard to define the magnitude of this phenomenon. However, it is known that children who grow up in poverty are especially 2014).

56 Philip Reichel and Jay Albanese, Handbook of Transnational Crime and Justice (US: Sage Publication,

57 Criminal Justice and Immigration Act, 2008, United Kingdom, Art 72(1). 
vulnerable to become victims of sexual exploitation, such as child pornography, child prostitution and trafficking.

In recent years, an alarming new development is the emergence of online prostitution syndicates in the major cities of Indonesia. Child sex workers and their pimps use the Internet to find their customers and communicate with them. Revealing pictures are posted on their social media profiles, or the profiles of multiple child sex workers are displayed on specific blogs or websites. Potential customers can scan through these children's profiles and get in contact with whomever they choose (sometimes through a 'mamih', another child who functions as a pimp). The communication with the customers then moves from the sites to internet-facilitated instant messaging services such as Blackberry Messenger. The financial transaction is done either through the internet or face-to-face when the child meets the customer. These child prostitution 'syndicates' are closely related to (biker) gangs, and children who work as child sex workers in these groups can later go on to become pimps themselves.

The Internet has also become a method to facilitate child kidnapping and trafficking. Social media and instant messenger services are used to get in contact with potential victims, charm them and lure them to an agreed location. There they are raped and drugged, which can be followed by extortion or even trafficking to be forced into prostitution. There is no accurate data on the number of children kidnapped and trafficked after meeting their abductor on the Internet.

In recent years, however, child sexual exploitation seems to have shifted from taking place in public and visible areas, to increasingly private domains, in large part due to the rise of Internet technologies. Chat conversations are held in private chat boxes, instead of on the streets. This makes this form of child abuse extra difficult to detect and therefore stop. The Internet has many features that can be used to facilitate the sexual abuse of children. In Indonesia, this has led to several distinct forms of online sexual abuse of children.

With the emerge of the Internet in Indonesia, different forms of abuse of children via the Internet have developed. Based on a recent case report in the media and on interviews with child victims and other key informants, four different forms of online sexual abuse of children in Indonesia have been determined.

Indonesian law states that causing pornography to be accessible to a child is a crime and a child who accesses pornography is a victim. Law Number 44 Year 2008 on Pornography mandates the protection of children from the impacts of pornography and the prevention of children from accessing pornographic information. ${ }^{58}$

Mobile internet technologies also help facilitate child prostitution and are used

58 See Law Number 44 on Pornography, Arts. 4 (1) and (2) and 16. 
by prostitution syndicates in Indonesia. Online sex workers (and their pimps) use social media, blogs and specific websites to promote themselves and get in contact with customers, and chat rooms and online instant message services to communicate with them. Looking for customers online gives child sex workers certain advantages compared to working on the streets or in bars: by looking for customers and arranging meetings with them over the Internet, they feel safer. They are protected from police raids as they do not need to solicit in the streets or in red-light districts. Particularly for child sex workers, the use of the Internet has advantages, because through online messages police cannot differentiate between child sex workers and adult sex workers, as opposed to working on the streets, where they are easily spotted by police officers. Additionally, by using the Internet as a way to attract customers, children do not necessarily need an adult pimp to act as a broker.

The occurrence of Online Sexual Abuse of Children in Indonesia is due to a factor that allows the perpetrators and the connecting parties to exploit certain groups of vulnerable children. Children are often used as commodities that provide financial benefits to the family. Cultural factors nourish this crime. Even in certain cases it seems that there is a social tolerance that embodies cultural practices that exploit children. There are some other factors that without being realized have made it occurs, such as allowing children to access the internet without any conscientiousness and consumerism that takes place in most children. Many actors take advantage of this weakness in trapping children to enter in an exploitative situation, so they freely exploit a culture that does not control the use of gadget by parents as an opportunity to make children as prey.

In many cases of Online Sexual Abuse of Children in Indonesia, girls are the largest group targeted by perpetrators. The vulnerability of this group of girls is due to cultural stereotypes that assess girls as weak, passive, obedient when compared with boys. In addition to this, the demand for girls is higher because girls are considered innocent and can give sexual satisfaction to the perpetrators of sexual crimes. Meanwhile, boys' groups, though in some cases, are targeted by sexual objects, but the numbers are small. From a gender perspective, girls should be acknowledged advancendely with regards to their equal status with boys. As most children exploitation put girls as a victim, a cultural approach may also be used by educating girls to get their awareness of the dangers of the online world, that especially may exploit their physical bodies. This would create a self-protection from Online Sexual Abuse of Children, so in case girls are persuaded by anyone or any online program, they will automatically reject it.

Another cultural factor that contributes to the high level of Online Sexual Abuse of Children in Indonesia is the unwillingness of parents to take a legal action by reporting violence experienced by their children. It seems that society has a lack 
of understanding of what is experienced by the child is a form of sexual violence. This situation is exacerbated by the absence or availability of reporting mechanisms provided by both law enforcement and government agencies. So the legal culture of reporting the case of the child is low and then aggravated by the unpreparedness of the government/law enforcement in encouraging the community to report it by providing an easy and credible reporting mechanism by the community.

In the community, there is also sought of sensitivity in preventing children from becoming victims of online sexual abuse. Society does not much involved in knowing these evil forms. They are indifferent to this situation, so this situation is used rightly by child sex offenders. Even public figures, as well as customary and religious leaders, do not properly aware about this issue. Such lack of awareness leads to a less prevention of the occurrence of online sexual abuse of children in Indonesia.

For the situations described above, this article submits that prevention measures should take into consideration the using of cultural approaches. From a basic knowledge of the law, a lesson on the purpose of law could be addressed. As it is generally known, the law does not only function to maintain the life of society only but also for the cultural values that remain sustainable and providing moral lessons. ${ }^{59}$ It may be reasonably argued that such an approach will gradually change the behaviour of society, especially families. A practical example, a socio-cultural campaign may be initiated to warn parents to take a proper means of supervision and control over their children when they use gadget. Such a campaign should be addressed to build a society sensitivity to the impact of information and technology on the safety of their children in the online world.

Fully considering that in developing countries like Indonesia, community and religious leaders play an important role to influence society mindsets, they should be targetted to become an agent of socio-cultural efforts in combating online child exploitation. Therefore, there is a necessity to not let them live in a traditional way by introducing an online world, especially gadget that has been widely used by children and teenagers. Once they realized the danger of Online Sexual Abuse of Children, they might react and disseminate it to the wider community by cultural means.

\subsection{Criminal Law Perspective on Online Sexual Abuse of Children in Indonesia}

According to the Indonesian legal framework, causing pornography to be accessible to a child is a crime, and a child who accesses pornography is a victim. The chances for a child to come in contact with harmful online content is reinforced by

59 Alimuddin Siregar, "Pornography Criminal Act on Pictures under the Law Number 44 Year 2008 about Pornography and Islamic Law In Indonesia” IOSR Journal of Humanities and Social Science 22, no. 10 (2017): 89. https://doi.org/10.9790/0837-2210118795 
the fact that in Indonesia, parents are often not Internet-knowledgeable and are unable to sufficiently guard and educate their children in this sense.

Law enforcers need to comprehensively understand the criminal acts of online prostitution because in many cases they can use more than one article from different laws for prosecuting the perpetrator. In Table 1 the different articles are displayed that can be attributed to cases of online sexual abuse of children.

\section{Table 1}

A Comparison of Regulation Related to Online Prostitution in the Criminal Code, Law Number 11 Year 2008 on Electronic Information, Transactions and Law Number 44 Year 2008 on Pornography and Law Number 23 Year 2002 on Child Protection.

\begin{tabular}{|c|c|c|}
\hline Act & Provision & Sanction \\
\hline Criminal Code & $\begin{array}{l}\text { Articles } 269 \text { and 506: } \\
\text { - An act which facilitates and } \\
\text { eases other people's indecent } \\
\text { act for his / her own gain. } \\
\text { - As a habit and livelihood. } \\
\text { - The perpetrator's act must be } \\
\text { done more than once. }\end{array}$ & $\begin{array}{l}\text { - Imprisonment of one } \\
\text { year and four months } \\
\text { and a fine of Indo- } \\
\text { nesian Rupiah (IDR) } \\
15.000 \text { (Article 296) } \\
\text { - Imprisonment of one } \\
\text { year (Article 506) }\end{array}$ \\
\hline $\begin{array}{l}\text { Law Number } 11 \text { Year } \\
2008 \text { on Electronic } \\
\text { Information and } \\
\text { Transactions }\end{array}$ & $\begin{array}{l}\text { Article } 27 \text { (1) regulates } \\
\text { prohibited acts: } \\
\text { - Any Person who knowingly } \\
\text { and without authority distri- } \\
\text { butes and/or transmits and/ } \\
\text { or causes to be accessible Elec- } \\
\text { tronic Information and/or Elec- } \\
\text { tronic Documents with contents } \\
\text { against propriety. }\end{array}$ & $\begin{array}{l}\text { - Any Person who sat- } \\
\text { isfies the elements } \\
\text { as intended by Ar- } \\
\text { ticle } 27 \text { shall be sen- } \\
\text { tenced to imprison- } \\
\text { ment not exceeding } 6 \\
\text { (six) years and/or a } \\
\text { fine not exceeding IDR } \\
1.000 .000 .000\end{array}$ \\
\hline $\begin{array}{l}\text { Law Number } 19 \text { Year } \\
2016\end{array}$ & $\begin{array}{l}\text { Article } 27 \text { paragraph (1) Juncto } \\
\text { Article } 45 \text { paragraph } 1 \text { prohibits } \\
\text { and convicts a person who tran- } \\
\text { scribes or distributes images con- } \\
\text { taining decency. }\end{array}$ & $\begin{array}{l}\text { not limited to the } \\
\text { tangible property, but } \\
\text { also the inta }\end{array}$ \\
\hline
\end{tabular}




\begin{tabular}{|c|c|c|}
\hline $\begin{array}{l}\text { Law Number } 44 \text { Year } \\
2008 \text { on Pornography }\end{array}$ & $\begin{array}{l}\text { Article } 30 \text { Juncto Article 4: } \\
\text { - More specifically regulates } \\
\text { criminal acts of running online } \\
\text { prostitution. The law categorizes } \\
\text { prostitution into some sexual } \\
\text { services such as explicitly pre- } \\
\text { senting genitals, exploiting or } \\
\text { exposing sexual activities; or } \\
\text { offering or advertising, directly } \\
\text { or indirectly, sexual services } \\
\text { as an objective element of the } \\
\text { criminal act. }\end{array}$ & $\begin{array}{l}\text { - A minimum term of } \\
\text { imprisonment of six } \\
\text { months and a maxi- } \\
\text { mum term of imprison- } \\
\text { ment of six years and } \\
\text { a minimum fine of IDR } \\
250.000 .000 \text { and a } \\
\text { maximum fine of IDR. } \\
\text { 3.000.000.000. }\end{array}$ \\
\hline $\begin{array}{l}\text { Law Number } 44 \text { Year } \\
2008 \text { on Pornography }\end{array}$ & $\begin{array}{l}\text { Article } 88 \text { prohibits: } \\
\text { - Every person who economically } \\
\text { or sexually exploits a child for } \\
\text { his/her own gain or the gain of } \\
\text { some third party }\end{array}$ & $\begin{array}{l}\text { - Imprisonment of not } \\
\text { more than ten (10) } \\
\text { years and/or a maxi- } \\
\text { mum fine of IDR } \\
\text { 100,000,000) (Euro } \\
\text { 6300). }\end{array}$ \\
\hline $\begin{array}{l}\text { Law Number } 35 \text { Year } \\
2014 \text { on Revision } \\
\text { Law Number } 23 \text { Year } \\
2002\end{array}$ & $\begin{array}{l}\text { Article } 76 \text { D, } 76 \text { E and Article } 82 \\
\text { paragraph (1) of Law no. } 35 \text { of } \\
2014 \text {. Article } 76 \mathrm{D} \text { is used if there is } \\
\text { a threat of violence against a child } \\
\text { to engage in sexual intercourse } \\
\text { with another child. Such threats } \\
\text { can be frightening or threatening } \\
\text { to spread pictures or other forms } \\
\text { of threat. Article } 76 \text { E children are } \\
\text { persuaded to commit abuse with } \\
\text { another child. It should be proven } \\
\text { whether intercourse has occurred } \\
\text { or is just obscenity. }\end{array}$ & \\
\hline
\end{tabular}

In a case law before District Court of Surabaya, the Court sentenced Tjandra Adi Gunawan four year in jail. ${ }^{60}$ He has been proven guilty of criminal acts to distribute and/or transmit and/or make accessible electronic information and/or electronic documents possessing violations of morality. ${ }^{61}$ In addition, the Court also found that he committed several acts of disseminating pornography containing nudity or an impressive display of nudity, sex, or child pornography. ${ }^{62}$

60 Decision of District Court of Surabaya (Putusan Pengadilan Negeri Surabaya) No. 2191/ Pid.B/2014/PN.Sby, Verdict Para 1

61 Ibid, Para 2.

62 Ibid. 
The cases illustrated above show that positive law still has not been able to give the perpetrator fear to not engage in sexual violence in children online. In addition, the proof of criminal acts of child sexual violence online is also not easy. Law enforcement takes a long time, and it takes an investigation strategy that uses technological means so that the perpetrators and victims can be identified.

\subsection{Online Sexual Abuse of Children Through the Lens of Environmental Criminology: A Situational Crime Prevention Approach}

The Environmental Criminology (EC) is a group of theories, which focus on the criminal events and the immediate environment in which those happen. EC is different from traditional criminology, which focuses on the offender in order to understand the "why" of the criminal action and, therefore elaborates treatments destined to the individual propensities.

EC theories, albeit not denying the role of personal inclinations, investigate the interactions between offenders, targets and the setting they find themselves in, highlighting the role of opportunity and circumstances in the commission of crimes. ${ }^{63}$ Immediate environment is not an incidental background of actions, but it has a primary role in incentivizing an action and influencing the way a behaviour develops. Since crime depends on situational factors, it cannot be random; hence, EC is practically oriented, being concerned with the individuation of patterns, in order to find feasible solutions to criminal events and elaborate effective crime prevention strategies.

\subsubsection{Routine Activity Theory (RAT) Applied to Online Child Sexual Abuse}

The Routine Activity Theory (RAT) ${ }^{64}$ upholds that crimes tend to concentrate where there is a convergence of three elements: a suitable target, a suitable offender and a hot location. Those elements - theoretically encapsulated in a double triangle ${ }^{65}$ - come into alignment due to the offender's and the victims' routines, which tend to separate them from guardians. ${ }^{66}$ Crimes' occurrence probability can be, therefore, determined as a function of the convergence of the aforementioned elements (Fig. 1). The RAT does not deny the role of personal inclinations but emphasizes the importance of the surrounding situation and opportunity when it comes to realizing the offence.

63 Richard Wortley and Lorraine Mazerolle, "Environmental Criminology and Crime Analysis: Situating the Theory, Analytic Approach and Application," In Environmental Criminology and Crime Analysis, ed. Richard Wortley and Lorraine Mazerolle, 1-15. (London: Willan, 2008): 1-15.

64 Lawrence E Cohen and Marcus Felson, "Social Change and Crime Rate Trends: A Routine Activity Approach," American Sociological Review 44 (1979): 588-608. DOI: 10.2307/2094589

65 John Eck, "Police Problems: the Complexity of Problem Theory, Research and Evaluation," Crime Prevention Studies 15 (2003),79-113.

66 Meghan E. Hollis, Marcus Felson, and Brandon C. Welsh. "The Capable Guardian in Routine Activities Theory: A Theoretical and Conceptual Reappraisal," Crime Prevention and Community Safety 15, no. 1 (2013): 65-79. https://doi.org/10.1057/cpcs.2012.14 


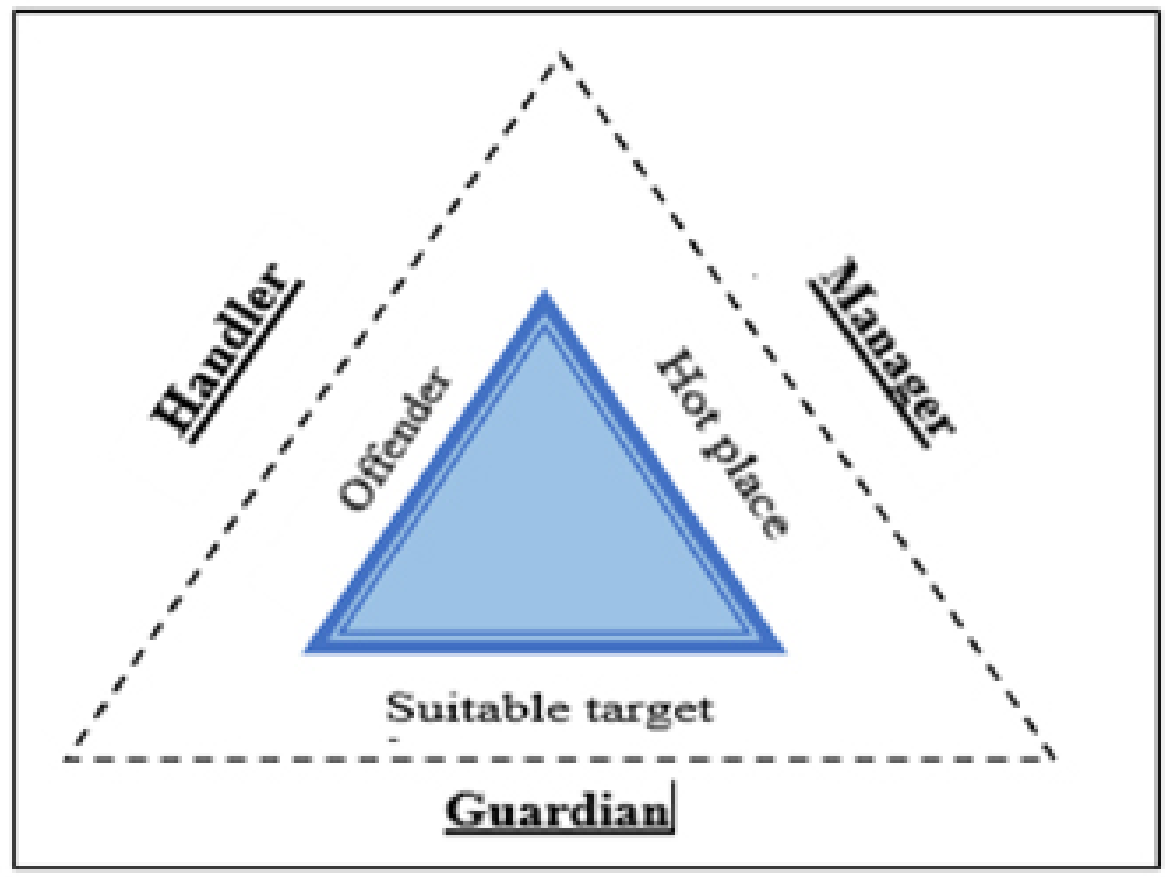

Figure 1

The Crime Triangle

The target suitability is evaluated in terms of both "targets' characteristics and surroundings." ${ }^{\prime \prime}$ Offences are more likely to happen when a suitable target and a motivated offender meet in the absence of a guardian.

The RAT has a wide applicability, since it can operate at different levels of analysis, both at micro and macro ${ }^{68}$ and can be applied to the case of child sexual abuse online as well. It is known that cyberspace can largely facilitate the commission of traditional crimes that acquire, in this way, a new occurring dimension. Several cases in the chronicles show how easily a man can lure into his prostitution ring young girls and then advertise their services online for other men to use. At the same time, the cyber space makes it way easier for offenders to get in touch with other offenders, creating a sort of network of like-minded perpetrators who can share information, suggestions and strategies. From this point of view, it immediately emerges how the internet functions as a "hot place".

Children have a remarkably easy access to the internet and most of the times in the almost total absence of parental control. Alongside this factor, the situation is worsened by the lack of social skills in children, compared with those of adults, ${ }^{69}$

67 Patricia L. Brantingham, and Paul J. Brantingham, "Environment, Routine and Situation: Toward a Pattern Theory of Crime" Advances in Criminological Theory 5, no. 2 (1993): 259-94.

68 Lawrence E. Cohen, Lawrence E., and Marcus Felson., Op.Cit.

69 Loreen N. Olson, Joy L. Daggs, Barbara L. Ellevold, and Teddy KK Rogers, "Entrapping the Innocent: Toward a Theory Of Child Sexual Predators' Luring Communication," Communication Theory 17, no. 3 (2007): 231-251. https://doi.org/10.1111/j.1468-2885.2007.00294.x 
and the absence of cues in the web to help them making a judgment about the trustworthiness of their interlocutors. Hence, "suitable targets" come closer to "offenders", when capable guardians are unable to intervene.

Given the role that opportunity plays in respect to child sexual exploitation, considering the occurrence of motivated offenders who are financially motivated, weak or mostly absent guardians and easy targets, ${ }^{70}$ Situational Crime Prevention (SCP) offers feasible and effective solutions to address the issue.

\subsubsection{Situational Crime Prevention in Online Sexual Abuse of Children}

When applied to the problem of child abusive material, the situational approach upholds the effects of opportunity over-consumption. Indeed, individuals can access resources, follow and satisfy their instincts in a cheap, fast and risk-free way. Several studies demonstrated that the issue of child pornography is escalated since the 1980s, with the spreading of the internet, which allows for a multiplication of materials immediately available and anonymously accessible. ${ }^{71}$

Given these considerations, it is obvious that the problem of CSE online cannot be addressed as a problem of individual sexual deviancy. ${ }^{72}$ The main approach of SCT is to reduce this opportunity while increasing the risks and diminishing rewards for perpetrators.

The strengths of SCT's suggested measures is that they are meant to prevent the act, instead than intervening on the consequences of it, and are not directed to one single individual, but aim to hit the environment facilitating the behavior of all. The main form of intervention is to reduce the opportunities for perpetrators. ${ }^{73}$ When the environment is manipulated in order to alter the offender's perception of the costs of his action, then the opportunities envisaged are reduced. Opportunities reduction when it comes to CSEO is enacted in three ways: increased the effort, increased the perceived risk and reduce the perceived reward. ${ }^{74}$

First of all, it is a matter of fact that offenders are more prone to commit crimes

70 Henry Hillman, Christopher Hooper, and Kim-Kwang Raymond Choo. "Online Child Exploitation: Challenges and Future Research Directions." Computer Law and Security Review 30, no. 6 (2014): 687698. https://doi.org/10.1016/j.clsr.2014.09.007

71 Philip Jenkins, Beyond Tolerance: Child Pornography on the Internet (New York: New York University Press, 2001); See also John Carr, Op.Cit.

72 Richard Wortley, "Situational Prevention of Child Abuse in the New Technologies," in Preventing Online Exploitation of Children, ed. K. Ribisl and E. Quayle (London: Routledge, 2012), 188-203.

73 Ronald V.Clarke, "Situational Crime Prevention," in Environmental Criminology and Crime Analysis, ed. Richard Wortley and Lorraine Mazerolle (London: Willan, 2008).

74 Note that the lastly theory formulated by Cornish and Clark (2008) outlines 5 strategies. The additional two are "removing excuses" and "reducing provocations". See also Derek Blaikie Cornish and Ronald V. Clarke, "Opportunities, Precipitators and Criminal Decisions: A Reply to Wortley's Critique of Situational Crime Prevention," Crime Prevention Studies 16 (2003): 41-96. 
that appear easier to realize. When child abuse materials are made more difficult to access, this creates an increase in the effort needed by the offender. Indeed, already by indirectly soliciting the moving of child pornography from the public to more hidden sides (which are used to escape policing radars), offenders are required a greater effort to access the contents: getting secret passwords, learning which wording to be used for searches, learning how to navigate the dark web.

Other ways to obtain a similar effect is to make it harder to send and receive pornography. Sometimes, the effort is increased by requiring a registration and/or identification to sites. However, there are many ways to share CE materials without recurring to those websites: peer-to-peer networks and anonymous remailers. ${ }^{75}$ By enacting stricter regulations of P2P networks and remailers systems, it would be possible to control the tools contributing to the realization of offences.

When the abusive material is sold, hence it has to be paid online, credit card companies could create mechanisms to automatically block, and maybe identify, the transaction. ${ }^{76}$

A solution like this would have a twofold effect: to raise the effort for users and reduce the monetary reward for those running the business. Therefore, by increasing the effort, if not a total reduction of crimes, there will be at least an influence on the number of offences committed by the same perpetrator. ${ }^{77}$

Second, increase the perceived risks. Given the sadly enormous amount of child abusive material consumers, it results almost impossible to prosecute all offenders. ${ }^{78}$ However, SCP theories stress the fact that perceived risks are something different from real risks. Internet anonymity is surely a factor prompting most of the offenders to act. ${ }^{79}$ If perpetrators had the feeling that they might be easily identified and eventually caught and prosecuted, their perception of risks would increase. This is the objective of internet policing, to create the impression of unsafety of the internet when it comes to retrieving child pornography.

75 Robert Lemos, "P2P Investigation Leads to Child-Porn Busts," Security Focus. August 19, 2008. https://www.securityfocus.com/brief/801; Jay Lynam, "Feds Crack Down on P2P Child Porn". Tech News World, May 17, 2004. http://www.technewsworld.com/story/technology/33836.html

76 Maxwell Taylor and Ethel Quayle, "The Internet and Abuse Images of Children: Search, Precriminal Situations And Opportunity," in Situational Prevention of Child Sexual Abuse, ed. Richard Wortley and Stephen Smallbone (NY: Criminal Justice Press, 2006)

77 An interesting view over this point can be found in Ronald V. Clarke and Patricia Mayhew, "The British Gas Suicide Story and Its Criminological Implications," in Crime and Justice, vol 10, ed Michael Tonry and Narval Morris (Chicago: University of Chicago Press, 1998).

78 Yvonne Jewkes and Carol Andrews, "Policing the Filth: The Problems of Investigating Online Child Pornography in England and Wales," Policing and Society 15, no. 1 (2005): 42-62. https://doi. org/10.1080/1043946042000338922

79 Christina Demetriou and Andrew Silke, “A Criminological Internet 'Sting': Experimental Evidence of Illegal and Deviant Visits to A Website Trap," British Journal of Criminology 43, no.1 (2003): $213-222$. https://doi.org/10.1093/bjc/43.1.213 
Police can adopt different strategies, involving infiltration into web-groups pretending to be fellow-offenders looking for CSE material, or children offering pornographic images or videos, in the attempt to unveil offenders. Undercover operations demonstrated to increase the number of arrests already in the USA. ${ }^{80}$ On a greater scale, police could also use so-called "honey trap sites," 81 which are able to identify the offender's IP or store credit cards information. When largely publicizing policing successes and increased rates in processes, law enforcement authorities could greatly contribute to raising the risks perception.

From another perspective, working on victims' identification could serve as an efficient tool as well. Victim identification is a methodology focused on images, photos and films analysis with which specialist all over the world work alongside their counterparts in order to get as much information as possible about the child abuse offence online starting from the victim.

This type of approach is based on fact that online child pornography of any kind generally portraits and shows victims much more than it does with perpetrators; hence, the necessity of an accurate analysis of the victims. Victim identification aims to identify and locates the exploited children in order to lately bring the abuser to justice.

In March 2009, INTERPOL launched the International Child Sexual Exploitation (ICSE) database, through which investigators and specialists all over the world are able to share data. ${ }^{82}$ Victims, offenders and places are carefully collected and compared into the database, in order to establish relevant connections and plan targeted operations. The ICSE database has been largely improved since 2016 to reaching a number of 29 countries, plus Europol, currently linked to this and therefore able to cooperate.

Lastly, the opportunity thesis upholds that offenders commit crimes in order to achieve a certain reward. In CSEO, the first outcome is sexual gratification. Making it more difficult to access child abusive material online would surely have an impact on the benefits perceptions. Services providers (ISP) should, therefore, implement self-regulations able to impact on the sharing of such images and video or, more generally, binding members to remove entire illegal websites. The use of hotlines, as well, is a way to enable other user reporting the existence of child pornography

80 Janis Wolak, Kimberly J. Mitchell, and David Finkelhor. Internet Sex Crimes against Minors: The Response (Alexandria, VA: Crime Against Children Research Center, University of New Hampshire, 2003).

81 An example of a successfull operation is "Operation Pin". For more information See BBC News, "Police Trap Online Paedophiles," December 18, 2003,

http://news.bbc.co.uk/2/hi/uk_news/3329567.stm

82 Interpol, "Towards a Global Indicator on Unidentified Victims in Child Sexual Exploitation Material," Technical Report. Bangkok: Interpol and ECPAT International, 2018. 
on the web, alongside the utilization of filters applied to the browser that either return no results to the search or alert the consumer if an illegal website is about to be entered. In order to stimulate ISPs to adopt such regulations, some measures implying financial pitfalls for the providers may be applied. Adegoke brings the example of major brands which have stopped advertising on networks that make child abusive material available. The application of SCP to online child exploitation has been quite limited so far, but it has clear theoretical confirmation. It is undoubtedly that it would be a powerful and effective tool to address an endemic and often overlooked issue.

\section{Conclusion}

Online child sexual abuse is evolving along with the rapid development of information technology. This crime is too strong to be dammed by relying solely on the law, because in reality the law does not frighten the perpetrator, and the law acts only when this crime has been committed. A criminal justice approach will not be effective in warding off this crime but a cultural approach is needed as an alternative to how to deal with it. A cultural approach is important because online child sexual violence appears unbalanced with the cultural ability to counter it. The current culture is incapable of preventing and even tackling this crime. No local wisdom has been able to cope with it and even tends to nourish this crime. Therefore, there needs to be a new culture that emerges based on local cultural values to tackle this crime problem. The trick is to strengthen the family's presence, foster gender justice and strengthen the knowledge of community leaders to be technologically literate and understand this new model of crime.

\section{Acknowledgement}

Opinion set out in this article are those of the authors. It does not reflect the opinion of their job affiliation. 


\section{BIBLIOGRAPHY}

\section{Book}

Beaulieu, Catherine. Strengthening Laws Addressing Child Sexual Exploitation. Bangkok: ECPAT International, 2008.

Carr, John. Child Abuse, Child Pornography and the Internet. London: NCH, 2004.

Jenkins, Philip. Beyond tolerance: Child pornography on the Internet. New York: New York University Press, 2001.

Reichel, Philip and Jay Albanese. Handbook of Transnational Crime and Justice. US: Sage Publication, 2014

Thornburgh, Dick, and Herbert S. Lin. Youth, Pornography and the Internet: Can We Provide Sound Choices in a Safe Environment?. D.C: National Academy Press, 2002.

Wolak, Janis, Kimberly J. Mitchell, and David Finkelhor. Internet Sex Crimes against Minors: The Response. Alexandria, VA: Crime Against Children Research Center, University of New Hampshire. 2003.

\section{Chapter in an Edited Book}

Clarke, Ronald V. "Situational Crime Prevention." In Environmental Criminology and Crime Analysis, edited by Richard Wortley and Lorraine Mazerolle, 178-194. London: Willan, 2008.

Clarke, Ronald V. and Patricia Mayhew. "The British Gas Suicide Story and Its Criminological Implications." In Crime and Justice, vol 10, edited by Michael Tonry and Narval Morris (Chicago: University of Chicago Press, 1998)

Madrinan, Carmen. "Worst Form of Child Labor: Commercial Sexual Exploitation of Children", in The World of Child Labor: An Historical and Regional Survey, edited by Hugh D Hindman, 95-101. New York: Routledge, 2015.

Taylor, Maxwell and Ethel Quayle. "The Internet and Abuse Images of Children: Search, Pre Criminal Situations And Opportunity." In Situational Prevention of Child Sexual Abuse, edited by Richard Wortley and Stephen Smallbone, 169-195. NY: Criminal Justice Press, 2006. 
Wortley, Richard. Situational Prevention of Child Abuse in the New Technologies. In Preventing Online Exploitation of Children, edited by K. Ribisl and E. Quayle, 188-203. London: Routledge, 2012.

Wortley, Richard and Lorraine Mazerolle. "Environmental Criminology and Crime Analysis: Situating the Theory, Analytic Approach and Application." In Environmental Criminology and Crime Analysis, edited by Richard Wortley and Lorraine Mazerolle, 1-18. London: Willan, 2008.

\section{Journal Article}

Tangkupi, Prima. "Cultural Approaches in Cyberporn Crime Prevention", Jurnal Dinamika Hukum 17, no.2 (May 2017). http://dx.doi.org/ 10.20884/1.jdh.2017.17.2.544

Brantingham, Patricia L., and Paul J. Brantingham. "Environment, Routine and Situation: Toward a Pattern Theory of Crime." Advances in Criminological Theory 5, no. 2 (1993): 259-94.

Budiman, Ahmad. "Pemblokiran Konten Porno pada Layanan over the Top," Info Singkat Pemerintahan Dalam Negeri IX, no. 22 (November 2017).

Chawki, Mohamed. "Child Sexual Abuse: The French Response", Journal of Digital Forensics, Security and Law 4, no.4 (2009).

Chawki, Mohamed and Yassin el Shazly. "Online Sexual Harassment: Issues and Solutions," Journal of Intellectual Property, Information Technology and Electronic Commerce Law 4, no.2 (2013)

Christianto, Hwian. "Imposition of Nature Against Material Law under Judge Verdict of Cyberporn Case In East Java," Jurnal Dinamika Hukum 17, no. 3 (September 2017). http://dx.doi.org/10.20884/1.jdh.2017.17.3.915

Cohen, Lawrence E., and Marcus Felson. "Social Change and Crime Rate Trends: A Routine Activity Approach" American Sociological Review 44 (1979): 588-608. DOI: $10.2307 / 2094589$

Cornish, Derek Blaikie, and Ronald V. Clarke. "Opportunities, Precipitators and Criminal Decisions: A Reply to Wortley's Critique of Situational Crime Prevention." Crime Prevention Studies 16 (2003): 41-96. 
Demetriou, Christina and Andrew Silke. "A Criminological Internet 'Sting': Experimental Evidence of Illegal and Deviant Visits to A Website Trap". British Journal of Criminology 43, no.1 (2003): 213-222. https://doi.org/10.1093/bjc/43.1.213

Eck, John. "Police Problems: the Complexity of Problem Theory, Research and Evaluation." Crime Prevention Studies 15 (2003):79-113

Flood, Michael. "The Harms of Pornography Exposure Among Children and Young People." Child Abuse Review, 18 (2009): 384-400. https://doi.org/10.1002/ car.1092

Hillman, Henry, Christopher Hooper, and Kim-Kwang Raymond Choo. "Online Child Exploitation: Challenges and Future Research Directions." Computer Law and Security Review 30, no. 6 (2014): 687-698. https://doi.org/10.1016/j. clsr.2014.09.007

Hollis, Meghan E., Marcus Felson, and Brandon C. Welsh. "The Capable Guardian in Routine Activities Theory: A Theoretical and Conceptual Reappraisal." Crime Prevention and Community Safety 15, no. 1 (2013): 65-79. https://doi. org/10.1057/cpcs.2012.14

Jewkes, Yvonne, and Carol Andrews. "Policing the Filth: The Problems of Investigating Online Child Pornography in England and Wales." Policing and Society 15, no. 1 (2005): 42-62. https://doi.org/10.1080/1043946042000338922

Krone, Tony and Russell G Smith, "Trajectories in Online Child Sexual Exploitation Offending in Australia". Trends \& Issues in Crime and Criminal Justice 524 (2017).

McCabe, Kimberly A. "The Role of Internet Service Providers in Cases of Child Pornography and Child Prostitution." Social Science Computer Review 26, no. 2 (2008): 247-251. https:// doi.org/10.1177/0894439307301438

Olson, Loreen N., Joy L. Daggs, Barbara L. Ellevold, and Teddy KK Rogers. "Entrapping the Innocent: Toward a Theory Of Child Sexual Predators' Luring Communication.” Communication Theory 17, no. 3 (2007): 231-251. https:// doi.org/10.1111/j.1468-2885.2007.00294.x

Putra, Angga Astian, Prija Djatmika, and Nurini Aprilianda. "Bentuk Perlindungan Hukum bagi Anak agar Tidak Menjadi Korban dari Tindak Pidana Pornografi melalui Situs Internet," Jurnal Hukum (2016). 
Siregar, Alimuddin. "Pornography Criminal Act on Pictures under the Law Number 44 Year 2008 about Pornography and Islamic Law In Indonesia” IOSR Journal of Humanities and Social Science 22, no. 10 (2017): 87-95. https:/ / doi. org/10.9790/0837-2210118795

\section{Dissertation}

Diriwari, Wilson Ola. "Efficacy of the Legal Frameworks for Child Protection in Nigeria." PhD diss., Department of Politics, History and the Brunel Law School Brunel University London, 2016.Decision, Indonesian Supreme Court, No. 100K/Sip/ 1967 dated14 June 1968.

\section{Legal Documents}

Convention on the Protection of Children against Sexual Exploitation and Sexual Abuse, Council of Europe Treaty Series - No. 201

Convention on Cybercrime, Council of Europe Treaty Series No. 185

ILO Convention No. 182 concerning the Prohibition and Immediate Action for the Elimination of the Worst Forms of Child Labour

Indonesian Criminal Code

Indonesia, Law Number 23 Year 2002 on Child Protection

Indonesia, Law Number 11 Year 2008 on Electronic Information and Transactions

Indonesia, Law Number 44 Year 2008 concerning Pornography

Indonesia, Law Number 35 Year 2014 concerning the Amendment to Law Number 23 Year 2002 on Child Protection

Indonesia, Law Number 19 Year 2016 concerning the Amendment to Law No. 11 of 2008 on Electronic Information and Transactions

United Nations General Assembly (2015), "Transforming our world: the 2030 Agenda for Sustainable Development", UNDOC, A/70/L.1

\section{Other Documents}

Adegoke, Y. Top Brands Start to Pull Ads from P2P Networks. New Media Age, April 24, 2003. 
Committee of the Parties to the Council of Europe Convention on the Protection of Children Against Sexual Exploitation and Sexual Abuse (T-ES), "Opinion on Article 23 of the Lanzarote Convention and its Explanatory Note Solicitation of Children for Sexual Purposes through Information and Communication Technologies (Grooming)," Adopted by the Lanzarote Committee on 17 June 2015.

Committee of the Parties to the Council of Europe Convention on the Protection of Children Against Sexual Exploitation and Sexual Abuse (T-ES), ${ }^{\text {st }}$ Implementation Report "Protection of Children Against Sexual Abuse in the Circle of Trust the Framework" Adopted by the Lanzarote Committee on 4 December 2015.

Deanna Davy "Regional Overview: Sexual Exploitation of Children in Southeast Asia" Bangkok: ECPAT International, September 2017

ECPAT International and Religions for Peace, "Protecting Children from Online Sexual Exploitation: A Guide to Action for Religious Leaders and Communities,” Bangkok and New York, June 2016.

European Commission, Home Affairs, Report of the Global Alliance against Child Sexual Abuse Online, December 2013.

Interpol, "Towards a Global Indicator on Unidentified Victims in Child Sexual Exploitation Material," Technical Report. Bangkok: Interpol and ECPAT International, 2018.

The Office of the United Nations High Commissioner for Human Rights, "New Digital Technologies Produce Unprecedented Levels of Child Abuse Material Online", 18 March 2016.

United Nations Glossary on Sexual Exploitation and Abuse Thematic Glossary of current terminology related to Sexual Exploitation and Abuse (SEA) in the context of the United Nations Second Edition, Prepared by the Task Team on the SEA Glossary for the Special Coordinator on improving the United Nations Response to Sexual Exploitation and Abuse, 24 July 2017.

\section{Case Law}

Decision of District Court of Surabaya (Putusan Pengadilan Negeri Surabaya) No. 2191/ Pid.B/2014/PN.Sbythe SEA Glossary for the Special Coordinator on improving the United Nations Response to Sexual Exploitation and Abuse, 24 July 2017. 


\section{Website Content}

BBC News. "Police Trap Online Paedophiles." December 18, 2003. http://news.bbc. co.uk/2/hi/uk_news/3329567.stm

Davit Setyawan. "KPAI: Darurat Pornografi pada Anak SD, Orangtua Harus Tingkatkan Pengawasan." March 31, 2018. http://www.kpai.go.id/berita/kpai-daruratpornografi-pada-anak-sd-orangtua-harus-tingkatkan-pengawasan

Emarketeer. "In Indonesia a New Digital Class Emerges: Internet and Mobile Internet Will See Significant Adoption in the Next Few Years.” March 12, 2013. http:// www.emarketer.com/Article/Indonesia-New-Digital-Class-Emerges / 1009723

European Commission, Migration and Home Affairs, "The Global Alliance Against Child Sexual Abuse Online." European Commission, Migration and Home Affairs, "The Global Alliance Against Child Sexual Abuse Online" https:// ec.europa.eu/home-affairs / what-we-do/policies / organized-crime-and-human-trafficking/global-alliance-against-child-abuse_en

Kompas, Situs Porno Kian Mengkhawatirkan Kompas.com, March 16, 2012, https: / / travel.kompas.com/read/2012/03/16/02354152/Situs.Porno.Kian.Mengkha watirkan\%E2\%80\%AC\%E2\%80\%AC

Lemos, Robert. "P2P Investigation Leads to Child-Porn Busts," Security Focus. August 19, 2008. https://www.securityfocus.com/brief/801

Lynam, Jay. "Feds Crack Down on P2P Child Porn”. Tech News World, May 17, 2004. http://www.technewsworld.com/story/technology/33836.html

Mason, Margie. Facebook Used to kidnap, traffic Indonesian girls. USA Today, October 30, 2013. http: / / www.usatoday.com/story/news/world/2012/10/29/ facebook-used-to-kidnap-traffic-indonesian-girls / 1665321/

Reuters, New Indonesia Internet System Blocks More Than 70,000 'Negative' Sites, Jakarta, February 19, 2018, http://indianexpress.com/article/technology/ tech-news-technology / new-indonesia-internet-system-blocks-more-than70000-negative-sites-5069746/

Tempo, "Kominfo Kantongi 8.166 Aduan Konten Pornografi di Januari 2018”, Bisnis. Com-Tempo.Co, February 23, 2018.https://bisnis.tempo.co/read/1063823/ kominfo-kantongi-8-166-aduan-konten-pornografi-di-januari-2018 